cadaver arm to be achieved. Separate measurements of trabecular bone mass, contical bone mass, and bone mineral concentration have also been achieved in patients. The results of this study have been presented in March 1975 at the International Symposium on Computer Tomography in Bermuda and will be further advanced at the European Society of Radiology in Edinburgh in June. It is impontant to stress that these results were obtained by modification of the E.M.I. brain scanner where the existence of a surrounding water reference makes accurate and absolute results possible.-We are, etc.,

IAN ISHERWOOD

R. A. RUTHERFORD

B. R. PUllen

Manchester Royal Infirmary and

University of Manchester

\section{Prevention of Overdoses}

SIR,-The inclusion of emetics in hypnotics proposed by Dr. P. M. Vicary (31 May, p. 503) to prevent the fatal overdose has been suggested before. There are barbiturates available, colleotively known as Barbemets, which contain a small amount of ipecacuanha. I attempted to assess the relative safety of these preparations by comparing the death rate per million prescriptions of Barbemets with conventional barbiturate preparations. Over the period 1965-70 there were $93 \mathrm{~m}$. prescriptions for barbiturates and 12354 deaths from barbiturate poisoning, a death rate of 133 per million presariptions. Over the same period 109000 prescriptions of Barbemets were issued and one death was recorded from a Barbemet preparation, a death rate of nine per million prescriptions, which would sug gest that Barbemets are indeed less of a risk, though the fact of only one death being recorded is insufficient for statistical confidence. In the course of the same inquiry nitrazepam was also investigated and gave a result of 11 deaths per million prescriptions, suggesting it to be safer than barbiturates.

However, Dr. Vicary asks how the commonly used hypnotics can be made safe for those who take overdoses, and the simple device of packaging in blisters or putting the active preparation in a mass of inent substance both warrant more official consideration, since the taking of large numbers of tablets is made much more difficult. For example, 50 tablets of nitrazepam $5 \mathrm{mg}$ weigh $27.5 \mathrm{~g}$, four times greater than 50 tablets of Amytal $100 \mathrm{mg}$, which weigh $7 \cdot 7 \mathrm{~g}$, a factor contributing to the greater safety of nitrazepam.

A more radical proposal for reducing barbiturate deaths is to stop the prescription of barbiturates by regulation. Even though the prescribing of barbiturates is diminishing as a result of voluntary restraint, deaths from barbiturates are reducing rather less fast.-I am, etc.,

\section{B. M. BARRACLOUGF}

M.R.C. Clinical Psychiatry Unit. Graylingwell Hospital,

Chichester, Sussex

\section{Beta-blockers and Fibrinous Peritonitis}

SIR,-We read with interest the description by Mr. J. F. Gurry and others (31 May, p.
498) of a further case of sclerosing peritonitis associated with treatment with practolol. We would urge caution, however, in accepting their suggestion that the more recent use of propranolol may have contriburted to the development of the lesion in their patient.

We have had referred to us two patients who developed sclerosing peritonitis, one two months and the other six months (also with pleural effusion) after stopping practolol; neither patient had taken any other beta-blocking drug. One of the patients reported by Brown et al. ${ }^{1}$ had a similar history and several others have been reported. ${ }^{2-4}$ Since the abdominal effects of practolol can thus be delayed, it is diffioult to implicate other beta-blocking drugs given at the same time or at a later date.-We are, etc.,

\section{R. P. H. THOMPSON} B. T. JACKSON

St. Thomas's Hospital, London S.E.1 Brown, P., et al., Lancet, 1974, 2, 1477.

3 Kristensen, K., Kristensen, J. S., and Thorborg, J. V., Lancet, 1975, 1,741. Medical fournal, 1975, 2, 337 .

** The authors sent a copy of this letter to Mr. Gurry and his colleagues, whose reply is printed below.-ED., B.M.F.

SIR,-I have had the opportunity to read the letter from Dr. Thompson and Mr. Jackson, and in the absence of my two coauthors, who are overseas, I would like to comment on it.

It is most reassuring to learn that cases of sclerosing peritonitis have developed after cessation of practolol therapy without the subsequent use of propranolol. Though there have been previous reponts of the delayed onset of peritonitis, the specific point of whether or not propranolol was used in the place of practolol has not been made until now.

In view of this report from Dr. Thompson and Mr. Jackson our cautionary note (31 May, p. 498) is no longer justified, nor is there any evidence to date to imply that propranolol therapy alone may cause this condition.-I am, etc.,

St. George's Hospital

IAN G. CUnNINGHaM London S.W.17

\section{Ocular Reactions to Beta-blockers}

SIR,-I should like to draw attention to the following case of corneal perforation occurring during treatment with beta-blocking drugs.

A 55-year-old man presented at this hospital in A 55-year-old man his left cornea perforated. He had suffered from angina for five years and had been started on propranolol in June 1970; this was continued for eight weeks, when practolol $500 \mathrm{mg}$ daily was substituted. He remained on this dose of practolol until April 1973 (32 months). In April 1973 he complained to his general practitioner about dry eyes and oxprenolol $40 \mathrm{mg}$ three times daily was substituted for the practolol. He remained on oxprenolol until July 1974, at which time the cornea perforated.

This case is not easy to assess in terms of causation. I accept that this man was taking practolol for about $2 \frac{1}{2}$ years before stanting oxprenolol; nevertheless, he had been off practolol and taking oxprenolol for a full 15 months before the corneal perforation. Clearly oxprenolol is not above suspicion and I feel that this is sufficient reason for the case to be reported.-I am, etc.,

Department of Medicine

J. R. W. LYALL St. Thomas's Hospital Medical School,
London S.E.1

\section{Anaphylactoid Skin Reaction after Intradermal Secretin}

SIR,-Drs. S. R. Bloom and A. S. Wand (18 January, p. 126) reported on the impairment of secretin release in patients with duodenal ulcer, thus substantiating the original idea of Demling et al., 1 who discussed deficiency of endogenous secretin as a potentially relevant factor in the pathogenesis of that disease. The fact that the secretin deficit in Drs. Bloom and Ward's short-history patients was as great as in their long-history patients may argue in favour of it being a primary defect.

While conducting a trial of exogenous secretin as a possible therapeutic agent in duodenal ulcer we obtained data possibly associated with immunogenic properties of that hormone. About 15 minutes after intradermal injection of 40 IU of synthetic secretin ${ }^{2}$ dissolved in $0.05 \mathrm{ml}$ of $0.9 \%$ saline subjects developed a local reaction resembling cutaneous anaphylaxis (unticaria plus surrounding erythema) indistinguishable from that following intradermal administration of $0.05 \mathrm{ml}$ of histamine dihydrochloride $(0.1 \mathrm{mg} / \mathrm{ml}$ of $0.9 \%$ saline). Urticaria and erythema vanished within 60-120 minutes. To study that phenomenon in more detail different groups of subjeots who had not previously received secretin were tested in the same way. Eight out of eight duodenal-ulcer patients showed anaphylactoid skin reactions to intradermal secretin, two out of three gastric ulcer patients, four out of six cases of ulcerative colitis or Crohn's disease, and 13 out of 23 subjects suffering from various gastrointestinal diseases other than those listed above (for example, chronic pancreatitis, gastric and colonic polyps, colon cancer) nterestingly enough, six out of seven healthy volunteers did not respond, while one healthy individual developed a questionable reaction. Systemic symptoms were noted in none of the subjects after intradermal secretin injection, nor was sensitization against secretin detectable in vitro when passive haemagglutination or blast-celltransformation techniques were employed.

Viewing the present preliminary data it may be suggested that there is-especially in duodenal-ulicer patients-a factor conditioning anaphylaotoid skin reaction due to intradermal secretin. An immunological mechanism based on the presence of secretin antibodies cannot be excluded-though there were positive reactions in subjects who had never before received secretin and in spite of negative in vitro tests. On the other hand, non-specific release of histamine or other vasoactive substances by secretin has not been reported so far. Whether or not there are relations between the impaired secretin release in duodenal uloer partients and a special immunological disposition of those patients against secretin is an un- 
answerable question at the moment and remains a challenge for future research. -We are, etc.,

\section{H. W. BAENKLER}

W. DOMSCHKE

S. DOMSCHKE

L. Demling

Departments of Immunology and Medicine, University of Erlangen-Nürnberg, Erlangen, West Germany

E. WƯNSCH

E. JAEGER

Max Planck Institute of Biochemistry,

München, West Germany

1 Demling, L., Ottenjann, R., and Gebhardt, H., Gastroenterologia, 1964, 102, 129.
Wünsch, E., et al., Chemische Berichte, 1972, 105 , Wünsch.

\section{Myocardial Infarction and Metabolism}

SIR,-In your leading article "Metabolism and Infarction" (14 September 1974, p. 643) you indicated that the extent of ischaemic damage could be altered by metabolic manoeuvres, including lowering the circulating free fatty acid concentrations, and you were kind enough to refer to the work of my group, which has now been published in preliminary form. ${ }^{1}$ However, your article suggested that metabolic manipulation may be effective only in the first hour or two after the onset of symptoms. But experimental myocardial infarction in the dog takes a week for the full extent of necrosis to be manifest. ${ }^{2}$ The experiments of Maroko et al. ${ }^{3}$ on dogs showed that glucose, insulin, and potassium therapy could reduce infarct size even when started three hours after coronary artery ligation, and in man Shell and Sobel ${ }^{4}$ have shown reduction in infarct size by reduction of after-load in hypertensive patients seven hours after the onset of rise of blood creatine phosphokinase-that is, probably about 12 hours from the onset of symptoms. Judged by decreased precordial ST-segment elevation, decreased ischaemic damage in man can be achieved up to 72 hours after the onset of symptoms, as shown by Shillingford's group. ${ }^{5}$ Conversely, experimental infarcts can be aggravated up to 72 hours afiter coronary artery occlusion by isoprenaline infusion. ${ }^{6}$

It would therefore seem that metabolic manipulation may well play a role even if started hours after the onset of symptoms, and every effort should be made to encourage the testing of the effect of reduction of circulating free fatty acids and/or promotion of glucose metabolism; glucose, insulin, and potassium therapy should do both. An effect of this treatment on infarct size in man has not been found, nor has it been looked for. To assess infanct size in man is not easy. Some of the principles and problemis in relation to the possible use of glucose, insulin, and potassium are outlined elsewhere. ${ }^{78}$ Other metabolic possibilities include the use of dichloroacetate to help influx of pyruvate into the citrate cycle, ${ }^{9}$ as suggested in your leading article.

Finally, it should be noted that it is increased cyclic AMP, and not AMP as stated in your article, which has been found in the blood of patients with acute myocardial infarction..$^{10}$ The cyclic AMP change may reflect increased catecholamine activity, which can also be monitored by plasma glycerol changes. ${ }^{12}$
The Chris Barnard Fund and the Medical Research Council of South Africa are thanked for support. -I am, etc.,

Ischaemic Heart Disease Laboratory,
Department of Medicine,

L. H. OPIE niversity of Cape Town

1 de Leiris, J., Lubbe, W. F., and Opie, L. H., Nature, 1975, 253, 746.
Cox, J. L., et al., American Heart fournal, 1968,

3 Maroko, P. R., et al., Circulation, 1972, 45, 1160 fournal of Medicine, 1974, 291, 481.

Pelides, L. J., et al., Cardiovascular Research, 1972, 6, 295 .

6 Shell, W. E., and Sobel, B. E., American fournal of Cardiology, 1973, 31, 474

Brachfeld, N., Circulation, 1973, 48, 459

8 Opie, L. H., American fournal of Cardio!ogy. In press.

jøs, O. D., Miller, N. E., and Oliver, M. F. European Society of Clinical Investigation, Strange, $R$. Clinical Investigation, $1974,4,115$

Rabinowitz, B., Kligerman, $M$., and Parmley, W. W., American Fournal of Cardiology, 1974 34, 7.

2 Carlström, S., and Gustafson, A., Britich Heart

\section{Abortion (Amendment) Bill}

SIR,-Your leading article (17 May, p. 352) and the subsequent statement given on radio by the Secretary of the Association in reference to the sit-in at B.M.A. House would suggest that the Abortion (Amendment) Bill is entirely evil and contrary to the highest standards of medical practice. The report of the Lane Committee is cited in support and you would have us believe that basically all is well with the present position. All is not well, and it is exactly because it is not that the Abortion (Amendment) Bill was introduced.

The 3243 terminations of pregnancy last year in girls under the age of 16 years should not be seen as an isolated phenomenon and unconnected with the present attitude to regard abortion as a form of contraception. We are told there is another answer to that too, which is to prescribe the pill to even younger age groups so that the whole country will be eventually "protected." Yet in spite of an already considerable extension of contraception for youngsters, the abortion figures in this group continue to rise.

You object to the introduction of adjectives such as "grave" and "serious," yet these have been used in medical practice for many years and have a greater reliability of interpretation than most others. The Bill introduced by James White was intended to make doctors face up again to their responsibilities and it is sad, though in this age not too surprising, to see a distinguished journal plead that doctors should not be asked to behave responsibly.

When one considers that upwards of $90 \%$ of the 150000 legal abortions arè done on psychiatric grounds when all the evidence shows that no "grave" or "serious" psychiatric threat to the mother's health exists it is not protection that the doctors require from its leading journal but exposure. And what of those doctors who, rightly, will not abort unless the threat to the mother is "grave" or "serious"? Are you suggesting that they are less worthy medical practitioners than the abortionists?

This medical stable is filthy and if we do not clean it out ourselves we cannot complain if others will do the job for us. There are still, fortunately, many doctors in this country who support the James White Bill and it is largely under pressure from many of my colleagues who share my views that I have written this letter.-I am, etc.,

MYRE SIM
President,
World Federation of Doctors who Respect
Human Life (British Section)

Queen Elizabeth Hospital,

Birmingham

SIR,-I am very weary of reading letters in the B.M.F. on sanctity and the "right of conscience" to abstain from giving medical help in abortion. How refreshing it would be to read some of real Christian concern and compassion for the woman in distress with an unwanted pregnancy and of some medical sense of responsibility in preserving her from the results of "back-street" abortion

The fetus in the great majority of unwanted pregnancies will die anyhow. It may be by a knitting needle, a crochet hook, slippery elm-bark, or drowning in the W.C. Or if it survives so far, being overlain or let die. But it will die. It is time this nonsense of writing and talking as if abortion was caused by the Abortion Act, came to an end. It is rubbish. Abortions occur. All doctors can do, and certainly have an obligation as doctors to do, is to try to ensure medical care for the woman where they can. And it is for this that the Act provides. Has a woman no right to compassion and medical care in unwanted pregnancy?

What Mr. White's Bill will do is to deprive the majority of women of medical aid in abortion and the conscientious doctor of his "right of conscience" to secure this for his patient, on pain of legal persecution. It will even be a crime for him to discouss her intentions with her. This is outrageous. And, had it not been for the way these aspects of Mr. White's Bill were glossed over to those who voted for it and the Bill slipped through quickly under its acceptable outer cover, it would have been flung out, as it should have been and should be now, as an affront to any humane society.-I am, etc.,

London N.W.3

Norman Chisholm

\section{Psychiatry in Russia}

SIR,-We recently had the opportunity to meet and confer with Dr. Marina Voikhanskaya, a Russian psychiatrist just arrived from Leningrad. Her testimony removed any vestige of doubt that Soviet psychiatrists certifying dissidents and human rights workers for compulsory detention know full well that there are no clinical grounds for detaining these "patients," who are wrongfully certified for reasons of political convenience. Psychiatrists in charge of dissidents in "special" and ordinary psychiatric hospitals are also cognisant of these facts and do not merely construe the concept of mental illness differently from their colleagues in the West. Hearing Dr. Voikhanskaya's evidence has convinced us that allegations of bad faith and misuse of psychiatry in the Soviet Union are all too well founded. She has asked us to submit 